\title{
WORD-FORMATION MEANS TEXTUAL COHESION AND COHERENCE
}

\author{
VASYL GRESHCHUK
}

\begin{abstract}
The article looks at word-formation means of textual cohesion and coherence. The analysis shows that the repetition of a suffix, prefix, confix or a base in adjacent or distant sentences in small textual segments can ensure the latter's cohesion. The 'source word - derivative' pair has a considerable cohesive potential. It is especially typical of syntactic derivation. The nominalization of the verb - the predicate of the base sentence, its communicative nucleus - and its use in the next sentence, adjacent or distant one, indicates the theme and ensures the communicative prospects of a sentence within the context of the developing and unfolding text. Textual cohesion is provided by 'source word - derivative' word-formation pairs beyond syntactic derivation - when we deal with mutation and modification. The components of complex word-formation units - wordformation paradigms, word-formation families - can be used as cohesive devices because they share the same root morpheme, which is the bearer of general semantic meaning inherent in all members of a paradigmatic grouping.
\end{abstract}

Keywords: cohesion, coherence, text, formant, base, word-formation paradigm, word-formation family.

One of the basic categories of text is its grammatical, semantic and thematic unity. Modern linguistics offers various interpretations of textual unity. Some scholars regard it as ties that bind sentences together, thus creating internal textual connections at the local level. It is also called textual cohesion. Others take a broader view on textual unity and define it as the unity of parts within the whole, the wholeness of text, its global unity. The ability of text to develop connections not only at the level of sentences or groups of sentences, but also at the level of the whole text is called coherence. Coherence and cohesion are heterogeneous manifestations of textual unity, which is realized through different linguistic means [1, p. 50-51; 2, p. 184-187; 4, p. 131-132; 6, p. 3-18]. This article discusses word-formation means of textual cohesion and coherence.

There is a whole range of word-formation units, from the simplest, elementary to complex ones: derivational morphemes, bases, derivative words, 'source word - derivative' word-formation pairs, word-formation paradigms, word-formation families, word-formation types and word-formation categories. All of them, each in its own way, can ensure the grammatical, semantic and thematic unity of text - at the local level or the global one, or both. Not only various word-formation units, but also features of word formation and word-formation phenomena that show themselves in text - wordformation motivation, kinds of word formation such as mutation, modification, transposition - should 
be regarded as the means that provide textual unity. Typically, it is repetition that makes it possible for the word-formation means to fulfill their cohesive function.

According to V.O. Lukin, 'the notion of repetition is so important because it is a defining factor in textual coherence: a sequence of signs is considered to be coherent due to the repetition of particular signs, their forms and meanings; being repeated, they link the sequence together, 'sew it together' into one separate whole ${ }^{\prime *}[9$, p. 24]. Thus it follows that the repetition of language units is one of the most important means of ensuring both cohesion and coherence of text.

Elementary word-formation units - word-formation formants, bases - are involved in the formation of text, in the realization of its categories not independently, but as parts of relevant derivational structures. The repetition of a particular suffix, prefix or confix in adjacent or distant sentences in small textual segments can ensure the latter's cohesion. Consider the following examples: Був період, коли послідовних боризів за незалежність України, за відродження української нації наші вороги називали "мазепиниями". Пізніше - "петлюрівияям". Затим - "бандерівцяями". Сьогодні таких людей називають pyхівиями** (Cited from V. Chornovil's speech at the 7th All-Ukrainian Congress of the People's Movement of Ukraine (often referred to as the Movement; Ukrainian: Pyx, Rukh); October 28, 1997) (There was a period when our enemies would call a staunch fighter for the independence of Ukraine, for the revival of the Ukrainian nation "Mazepivets". Later, "Petliurivets". Then,"Banderivets". Now such a person is called "Rrukhivets"***); А минущість, починаючи з другої половини того березня, стала моїм демоном номер один. Минущість і тимчасовість, і зникомість - скільки ще назв у ццієї примари? (Yu. Andrukhovych. Leksykon intymnykh mist) (And, beginning from that second half of March, transitory existence became my demon number one. Transitory and temporary, and momentary - how many more adjectives can describe this phantom?) (Yu. Andrukhovych. The Lexicon of Intimate Cities); Haйогидніші очі порожні, I Найгрізніше мовчить гроза, / Найнікчемніші душі вельможні, / Найпідліша брехлива сльоза. / Найпрекрасніша мати щаслива, / Найсолодші кохані вуста, / Найчистіша дуща незрадлива, / Найскладніша людина проста проста (V. Symonenko. Naiohydnishi ochi porozhni) (The most disgusting are blank eyes, / The most threatening is the silence of a storm, / The most worthless are the souls of grandees, I The most treacherous are false tears. / The most beautiful is a happy mother, / The most desired are the lips of your love, / The most faithful is the heart of a true friend, / The most complex is a simple person) (V. Symonenko. The Most Disgusting Are Blank Eyes); I все більше від нього відаляється / мій материк. / Можна все переплакати. Перебути. / Свій жаль перешарпати (O. Slonovska. Shchos take zapodiialos) (Ever further from him / moves my continent. / It helps, crying over it all. Musing over it all. / Trying to get over this pain) (O. Slonovska. Something Miserable Has Happened).

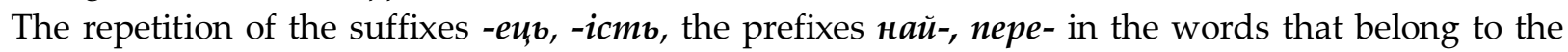
same word-formation type links together the sentences, in which they are used, 'sews them together', thus creating a segment of text on the basis of formal and semantic unity of its components; 'repetition at the semantic level, together with the repetition of the parts of a word that have a similar form (most often derivational morphemes), sets a specific sound pattern, which makes texts of both poetry and prose sound "poetical"' [5, p. 21].

Similarly, textual cohesion can be achieved through the repetition of the base in the structures of derivatives with different formant morphemes. The repetition of the base in derivatives with different lexical meanings is an important factor ensuring both cohesion and coherence, since the semantics of the base is more concrete than that of formants, and it is the base that conveys the meaning common to a group of base-related words. The 'source word - derivative' pair is the simplest example of how the repetition of the base can serve the function of creating text.

\footnotetext{
* In this article, all the quotations are translated from the sources listed in References.

${ }^{* *}$ Here and below, emphasis added. The study is based on the Ukrainian language; the examples illustrate specifically Ukrainian means of ensuring textual cohesion and coherence. The translations preserve the content of the original texts, but not their morphological or lexical form.

${ }^{* * *}$ Mazepivets, Petliurivets, Banderivets, Rrukhivets - Ukrainians committed to the idea of national independence; derivatives of the names: I. Mazepa, Hetman of Zaporizhian Host in 1687-1708; S. Petliura, Supreme Commander of the Ukrainian Army and President of the Ukrainian National Republic in 1918-1921; S. Bandera (1909-1959), revolutionary, politician and ideologue of the Ukrainian nationalist movement; Rukh, Ukrainian centre-right political party, founded in 1990.
} 
The 'source word - derivative' pair is the most common cohesive device that ensures textual unity, especially in the case of so-called syntactic derivatives [8, p. 57-70], derivative verbal nouns, derivative adjectival nouns, which have developed the abstract meaning of thingness. The nature of such derivatives is reflected in their names: having the features of the noun, they convey the lexical meanings of action, state, property typical of their source words and perform the syntactic functions of the subject and the object, which are not characteristic of verbs and adjectives. The phenomenon of syntactic derivation is correlated to transposition as a kind of word formation [12] and to one kind of nominalization [10, p. 39-52]. According to R. Z. Muriasov, 'nominalization is, first of all, repetition, indication, i.e. a kind of indicative deixis' [10, p. 48]. The nominalization of the verb - the predicate of the matrix sentence, its communicative nucleus - and its use in the next sentence, adjacent or distant one, indicates the theme and ensures the communicative prospects of a sentence within the context of the developing and unfolding text [10, p. 46]. Consider the following examples: Венеціл туманна. Ї̈ туманність у рази насиченіша від лондонської чи будь-якої іншої (Yu. Andrukhovych. Leksykon intymnykh mist) (Venice is foggy. Its fogginess is far more intense than that of London or any other one) (Yu. Andrukhovych. The Lexicon of Intimate Cities); (Я була малою горда, - Щоб не плакать, я сміялась... / I, забувши давню гордість, / Плачу я, щоб не сміятись (Lesia Ukrainka. Yak dytynoiu, buvalo) (My pride would then assert itself: / I laughed in order not to cry ... / And so, surrending my pride, / I cry in order not to laugh) (Lesya Ukrainka. As a Child, I Sometimes Fell [13, p. 73]; in the original Ukrainian text the author uses the words zордa - proud and гордість - pride); Ми чомусь досить відверто пишалися 3 извого приводу. В еСеСеСеРі, з якого до справжнього Парижа переважно не їздилося, підставою для пишання могло стати навіть цее (Yu. Andrukhovych. Leksykon intymnykh mist) (For some reason, we were proud of this fact. In the Soyuz Sovetskikh Sotsialisticheskikh Respublik (U.S.S.R.), from which people did not typically go to Paris, even this could become something to take pride in) (Yu. Andrukhovych. The Lexicon of Intimate Cities).

Textual cohesion can be provided by 'source word - derivative' word-formation pairs beyond syntactic derivation, when we deal with mutation and modification. For example, Я заздрив йому $i$ ревнував ї̈. Зрештою, в поляків це чомусь одне й те саме слово, ти знаєи. Я жахливий ревнивець, особливо, коли йдеться про изілком незнайомих дівчат, які при мені виявляють закоханість у своїх супутників (Yu. Andrukhovych. Leksykon intymnykh mist) (I was envious and jealous of him. After all, you know that the Poles, for some reason, use the same word for both things. Jealousy is my second name, especially when it concerns absolutely strange girls showing romantic feelings for their companions in my presence) (Yu. Andrukhovych. The Lexicon of Intimate Cities); Я, ніби Отто фон Ф. з пивбару на Фонвізіна, прагнув їм заперечувати. Я заперечував будь-яку вищість російського, а для цьвого мусив їх шокувати. Моӥм шокером була зневага, а моя зневага формою визволення (Yu. Andrukhovych. Leksykon intymnykh mist) (I, like Otto von F. from the beer hall on Fonvizin Street, desired to contradict their opinion. I denied the superiority of whatever is Russian; to beat them, I had to shock them. My shocker was contempt, and my contempt was a form of liberation) (Yu. Andrukhovych. The Lexicon of Intimate Cities). Typically, micro-text contains a source word in the context of a complete motivational statement, whose derivative is a bridge between the preceding and the following segments of text; for instance, Нині він [правнук Юрія Шкрібляка] дає новий поштовх гуцульській різьбі. Новатор (S. Pushyk. Pero Zolotoho Ptakha) (Nowadays he [Yurii Shkribliak's grandson] gives a new impetus to the Hutsul art of woodcarving. An innovator) (S. Pushyk. A Feather of the Golden Bird).

The logic behind the creation of text that contains 'source word - derivative' word-formation pairs does not always reflect the logic behind motivational relations in word formation. The components of the 'source word - derivative' pair can be used in direct or inverted order; in both cases they enhance textual cohesion. At the same time, when in a certain text a derivative precedes its source word (inverted order), in addition to performing cohesive function, it obtains the meanings of circumstantiation, concretization, specification, classification and other semantics. For instance, Про нього люди казали, що він богує. Він був як бог, знаючий $і$ сильний, той градівник $і$ мольфар. В своїх дужих руках тримав сили небесні й земні, смерть і життя, здоров'я маржини й ююдини, його боялись, aлe nотребували всі (M. Kotsiubynsky. Tini zabutykh predkiv) (People said he was a god. He was god-like, 
endowed with knowledge and power, that healer and wizard. In his strong hands, he held the forces of heaven and earth, death and life, the health of both cattle and humans; he inspired fear, but everybody needed him) (M. Kotsiubynsky. Shadows of Forgotten Ancestors); Так ти питаєш про обереги? Вони онде, на кінцяя рушників. Це такі, щоб ти знав, добрі охоронці нашого осідла, бережуть, аби до хати не заходили домовики <...> і ще запам'ятай: обереги боронять свою Берегиню від домовиків (V.Skurativsky. Berehynia) (So you ask about me apotropaics? There they are, on the ends of the embroidered towels. Listen to what I tell you, they are the guards of our dwellings, they protect our homes against hobgoblins $<\ldots>$ and one more thing you should remember: apotropaics guard their Protectress against hobgoblins) (V. Skurativsky. Protectress).

The repetition of the base is not confined to the 'source word - derivative' word-formation pairs; it can occur if a pair of derivatives share the same base, but have affixes with opposite or different meanings. In such cases, textual cohesion is based on the repetition of the same base in the structures of derivatives whose formants not only indicate the difference between them, but also emphasizes the repetition as a device that ensures cohesion through the overlaid meanings of polarity, contiguity, semantic affinity and dissimilarity, etc. Consider the following examples: Я б віддав отой химерний / Твій таємний світ надхмарний / За наземне справжне графство, / За підхмарний замок гарний (Lesia Ukrainka. Davnia kazka) (I would give that ephemeral / Secret world of yours in the skies / For a real county on the earth, / For a handsome castle standing under the skies) (Lesya Ukrainka Ancient Fairy Tale); Потомки розберуться. Їм видніш / крізь кришталево-об'єктивну призму - / хто був мистцем, а хто ховав фетиш / простацтва за щзитом соиреалізму. / Простацтво - це іще не простота. / Шукання форми - це іще не поза. / Аиш фанатичний пошук дороста / до простоти мистия і віртуоза (L. Kostenko. Zorianyi intehral) (Our posterity will make their judgment. Looking through / the crystal prism of objectivity, I they will tell artists from those who fetishized / simplemindedness, hiding behind the shield of socialist realism. I There is a difference between simplemindedness and simplicity. I Seeking a form cannot be claimed an opinion. I Only a fanatical search can bring an author / to the simplicity of a true artist, a virtuoso) (Lina Kostenko. Star Integral); Ми говоримо про державу, їі народження в муках. Державники - обов'язково патріоти, хоча й дотримуються часом різних поглядів у впорядкуванні держави. Антидержавники - теж патріоти, але... інших держав. I інших мов (A. Mokrenko. Tsvit i korin materynky) (We speak about the state, witnessing it in the painful labor of birth. State leaders must be patriots, though they may adhere to different principles of state formation and development. Anti-state leaders are also patriots, but ... of other states. And of other languages) (A. Mokrenko. Oregano Flower and Root).

Both the word-formation paradigm as a complex word-formation unit, whose co-derivatives share the same base, and the word-formation family as the aggregate of words that share the same root morpheme and are systematically organized according to derivational principles can provide textual coherence. The latter can be realized through the repetition of the base in the words that share the same base or the same root. 'Derivatives with the same root morpheme and different derivational formants that are intentionally introduced into a literary text specify the general semantic idea inherent in the above morpheme; in other words, this idea is specified in the derivative meaning of lexemes, which enables the author to express their thoughts and attitude, and provides the coherence of a given text, its integrity and wholeness' [3, p. 111].

Consider several excerpts from S. Pushyk's essay Daraby plyvut u lehendu (Darabas* Float into Legend), a story about the last timber rafting down the Cheremosh River in the Carpathian Mountains. Its thematic unity is based, among other things, on the repetition of the components of the word-formation family with the main constituent плисти (пливти) ((to) float). The derivatives sharing the same root

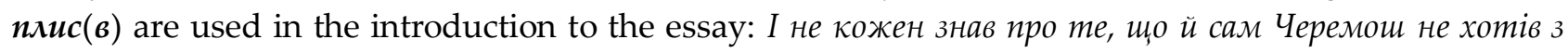
циим змиритися, щз він уже не буде вважатися робітником лісової промисловості, що на нвому закінчуеться велика епоха карпатського лісосплаву, якій не менше двох тисячоліть. Черемош не хотів змиритися з изим! Той останній сплав був пущений з верхів'я Білого Черемоша, з урочища Верхня Яловичара, ще 9 серпня, у четвер. Але тих 335 кубометрів, той караван, того дня до Вижниці не доплив, бо Черемош збунтувався, як гордий гуцул. якого хочуть позбавити назавжди честі та слави; великі зливи

\footnotetext{
Daraba - a timber raft in the Carpatian Ukraine.
} 
прошуміли горами, велика вода йшла Черемошем, несла дарабу, і плотогони вирішили зупинити пліт 8 урочищі Мар'їнім, де такі небезпечні пороги та коліна, де штучне озеро-кляуза рятувало життя плотогонам, і той пліт, ота остання дараба дочекалася на прия'язі суботи, 14 серпня. (Fеш реорlе kпеш that the Cheremosh himself could not believe it - he would not be called a worker of the forest industry any more, it was the end of the no-less-than-two-thousand-year-long epoch of timber rafting in the Carpathians. The Cheremosh refused to accept it! The last timber raft was sent from the upper reaches of the White Cheremosh, from the river of Verkhnia Yalozychora, on Wednesday, August 9. But that 335-cubic-metre caravan did not reach the town of Vyzhnytsia that day, because the Cheremosh rebelled, as a proud Hutsul*, whom they want to deprive of his honour and glory; heavy showers stormed over the mountains, great waters rushed down the Cheremosh, taking the rafts along with them; and the pilots decided to stop the raft near Marine, where the rapids and the bends were so dangerous, where a 'klause', a man-made lake on the dammed river, could save their lives; and there that timber raft, that last daraba, had to wait, moored to the bank, till Saturday, August 14.)

Further in the text, the author uses other derivatives, which contain the same nхuc(b) root morpheme, and repeats the above ones. Consider the following excerpt: Дуже скоро почалася тогорічна весна й у черемоських сплавників: 24 березня з села Устеріки, де стрічаються Біла з Чорною рікою, а трошки нижче з буковинського боку вплітаеться й річка Путила, прикрашений і прапорияли плив перший сплав; В понеділок, як і завжди, рано-вранцуі везли машини сплавників у верхів'я річок; Плотогони, хоч $і$ сплавляли ліс, із Буковини, хоч і рахувалися робітниками Вижницької сплавконтори, були з села Владів-Ростоки; За технікою безпеки стороннього на сплав не беруть. Для письменника зробили виняток, і мені було якось маркотно на душі, щзо пливу не як робітник, а як капітан, хоч ніким не командую...; Вже дві години ми на воді. Діти біжать від школи на пліт подивитися, машина сигнал подає - вітаеться шофер. Старий гуцул у сардаці, в рогатій шапці, з файкою в зубах став і посліхається - свою молодість згадав, а літа його, мов ті дараби, попхивли вже вдалину. Стоїть старий... Губчук розказуе, що з чотирнадияти хіт пішов плотогонити. (Fоr the Cheremosh timber rafters, spring started early that year: on March 24, the first timber raft, decorated with little flags, started from the village of Usteriky, where the White and the Black Rivers meet, and a bit lower the river Putyla joins them from the Bukovynian side; As usual, cars took the timber rafters to the upper reaches of the rivers early on Monday morning; Though the timber rafters took the raft down from Bukovyna, though they worked for the Vyzhnytsia timber rafting firm, all of them were from the village of Vladiv-Rostoky; Under the Occupational Safety regulations, outsiders are not allowed on a timber raft. They made an exception for an author, and I felt uneasy about being idle on the raft - like a captain without a crew...; We have already been on water for two hours. A group of children is running out of the school yard to watch the raft, a car is beeping - the driver is greeting us. An old Hutsul wearing a sardak* and a horned hat, a pipe between his teeth, stands smiling - recollecting his youth; his young years, like darabas, have already floated away. The old man is standing still... Hubchuk says he started timber rafting at fourteen.) The components of the above word-formation family are repeated in the final part of the essay. Consider the following excerpt: Колись у телепередачі "Клуб мандрівників" показували, що фінни так само сплавляють ліс, як $і$ в Карпатах гуцули. Правда, там в основному дикий сплав, але і дараби пускають. На дарабі будують будку, бо ж Фінляндія не Західна Україна - холодніше там, сиріше. Та й сплави, оповідав диктор, пливуть тільки під час повеней, коли тануть сніги. А верховиниялм доволі було багажника посеред нашої талби-ланки. (We used to have a TV programme called 'The Travellers' Club'; and once they showed timber rafting in Finland. It is similar to the way the Hutsuls do it in the Carpathians. Timber rafting in Finland is mostly natural, but they make darabas as well. They construct a cabin on a raft, because Finland is not Western Ukraine - it is colder and wetter there. According to the host of the programme, they drift timber rafts only during the snow-melting flood period. As to the Verkhovynians ${ }^{* * *}$, they need just a boot on one of the sections of a raft.)

In Ukrainian, the source word $\boldsymbol{л и с т и ~ ( ( t o ) ~ f l o a t ) ~ a n d ~ i t s ~ d i r e c t l y / i n d i r e c t l y ~ m o t i v a t e d ~ d e r i v a t i v e s ~}$ nоплисти (float away), nхim (timber raft, raft), сплавляти (take a timber raft down the river), cnхав (timber

\footnotetext{
${ }^{*}$ Hutsul - Hutsuls are an ethnic group of Ukrainians inhabiting the Carpathian Ukraine.

${ }_{* * *}^{* *}$ Sardak - a short wool coat, a traditional Hutsul garment.

${ }^{* * *}$ Verkhovynians - people who live in Verkhovyna, the Hutsul region in the Ukrainian Carpathians; Verkhovyna is also the name of an urban-like settlement, the administrative center of Verkhovyna District.
} 
rafting), сплавник (timber rafter), лісоспхав (timber rafting), сплавконтора (timber rafting firm), плотогон (timber rafter, pilot), плотогонити ((to) raft timber) have the same root morpheme, but different lexical meanings; their sequential use in the text unites its parts into a single whole. These words are the key points in the thematic structure of the coherent text.

Word-formation paradigms and word-formation families help to achieve textual coherence, especially when the thematic unity is brought out by a (non-)derivative word in the title of a macro-text and is maintained in the story through the repetition of its derivatives that share the same base or root morpheme, but perform different functions.

For example, the theme of Vasyl Stefanyk's novella Pidpys (The Signature) is encapsulated in its title; nidnuc (signature), a derivative verbal noun, is a semantically capacious word. The Signature is a story about how a little girl named Dotsia teaches illiterate old farmers to sign their names so that they do not have to pay ynic - the guarantor's fee for signing a document. The theme is introduced in the title; then it develops, getting enriched with details and concrete facts, and comes to its logical conclusion due to the extensive use of derivatives that share the same root morpheme nuc- (write, sign).

In rather a short novella, the author uses eighteen derivatives that share the same root, but belong to different parts of speech. The morpheme is the structural and semantic core of both the novella's title and a group of nominal and verbal derivatives of the intransitive verb nucamu (write), it binds the text together, structurally and semantically. The source word is used in the very first sentence of the novella: Мала Доця ходила лавою поза плечі газдів, щчо писали коло довгого стола свої імена. (Little Dotsia was walking along the bench behind the farmers, who sat at a long table writing their names.) In the next sentence, the author uses a derivative, the nominal deverbative nucapi (scribes; here - the persons who learn to spell their names), which drives the story on: Грубими руками оті писарі обходихи з кожного боку, звідки би найліпше їм почати. (With their rough hands, those scribes tried to start from this end, then from that end.) The thematic unity of the next fragment is maintained through the repetition of the source word писати (write): А білявенька Доця заглядала до кожного, чи добре пите. - Доцью, ня, а подивиси, як воно виглядае? - Ще чепірнате таке, як нечисане повісмо, що пишіть. I газда пхав олівце в pom i зачинав знов писати. (And fair-haired little Dotsia kept glancing at everybody's paper to check whether they were writing well. 'Dotsia, come 'ere, wha' yeh say - how does it look?' 'Still looks tousled - like raw yarn, yeh keep writin'.' And the farmer would put the tip of a pencil into his mouth and start writing again.) There are two verbal derivatives that indicate the aspect of the action; they also ensure the thematic unity of the text: - Ану ж ко, глипни на моє, бо я вже єго чешу другий вечір, аж ні груди больи. Ану читай, що я написав. - Павло Аазиренко. - Якурат я. Та так воно там стоїт, ио кождий пизнает? - Хто вчений та й кождий. I Павло почервонів з утіхи, і оглядав карточку з усіх боків. - Ану ж ко я ще раз єго віпишу. ('C'mon, have a look at mine, cos I'm already neatenin' it fer two nights, givin' me a pain in me chest. C'mon, read what I wrote.' 'Pavlo Lazyrenko.' 'Right, $t$ 's me. So it is there an' everybody can reads it?' 'Everybody who knows readin'.' Pavlo's face got red with pleasure, he was turning the card in his hands and looking at it from all sides. 'Lemme draw it one more time.')

In the text, the deverbative nouns nucbмo (writing) and ynic (the guarantor's fee for signing a document) perform the same function. Due to its semantic and syntactic characteristics, the noun nисьмо can name the action conveyed by the source verb nисати (write): Ви, мой, $i$ молодi, $i$ вчітеси, виджу, письма та й нічо не знаєте. (Look, yeh're youn', and I see yeh learn writin', but yeh donna know nothin'.) It should be mentioned that in this novella, the deverbative noun nuсьм⿻ is also used in the meaning of писаний документ (a written document, a paper) that is semantically related to the verb $n u$ сати: - Вібачєйте мені, пане, бо я непорозумів, а папері аді гезди. - Та й вітег з пазухи, та й подав. - Там, - кажу, - дес евсе, бо я то докупки все складаю, все письма. - Хлоп, - каже, - все дурний, гние цзілу зиму та й би не навчивси навіть свое порекло на письмі покласти. ('I'm sorry, me lord, I didn't get it, an' the papers are here.' An' I pulled them out from me bosom and gave them ter 'im. 'It's all somewhere there,' I tell 'im, cos I put them all together, all them papers.' 'Yeh stupid peasants,' say he, 'rot fer the whole winter an' can't even learn how ter write yer names ter sign a paper.')

The deverbative noun ynic, a derivative with the same root morpheme, is another means to provide the thematic unity of the text; it is one of the key components of its semantic structure: $-A$, npouy, no- 
кладу знак своєв руков, аді хрестик, а ви підпишіт... - Не можна, каже, на вексльих хрестиків класти... - А я в гадках став. Це як озмут упіс, як процент наперед відберут, як нотареви заплатю, та й того капіталу махо шо мені хишитси. ('I tell 'im, "I'll put a sign with me own hand - a cross, see, an' yeh put yer signature on it..." "No," say he, "you can't put crosses on promiss'ry notes..." Wait a minute. Pay fer the guarantor's signature, pay the interest in advance, pay the notary - there'll be not much money left fer meself.')

In the final part of the novella, its thematic unity is achieved through the use of perfect and non-

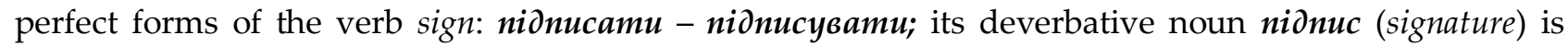
used as the title of the novella: - Поклав-сми гроші у скриню, а сам до Доці. Ти, Доцзько, діда навчи підписати намено, най дір панам горло не напихае, бо воно напхане. Я волію тобі плахтиночку купити... - Та й навчила та й сте по селі перечули, та й сте з діда насьміхалиси. Але прийшло до крутого, траба викслі підписувати, а ви за дідом до Доці. Я вам дорогу показав, шо вже не мете гроші yтрачьити. ('I put the money into a chest and went to Dotsia. "Look, Dotsia, teach the old man how ter sign'is name, why should he feeds those greedy lords, they're already stuffed full. I'd rather buy you a nice little plakhta"..." And she taught me how ter sign me name an' the rumour went around the village, an' they laughed at the old man. But it so happened yeh had ter sign promiss'ry notes, an' all of yeh followed in me footsteps ter Dotsia. I showed you how not ter lose yer money.')

Thus, the components of the word-formation family that share the same root morpheme nuc- (write, sign) serve as a kind of architectonic frame in the formal semantic structure of Stefanyk's novella The Signature; they ensure a fundamental property of text - its thematic unity [3, p. 111-112].

M.M. Poliuzhyn is right to state that 'The totality of repeated adjacent and distant members of a paradigmatic grouping creates the thematic net of a literary work, binding together separate fragments of a text in accordance with the principle of thematic unity. As a result, each time a derivative appears in a text, it triggers associations that characterize the whole paradigmatic grouping, highlights the situation already known and indicates the direction in which the story develops' [11, p. 90].

In conclusion therefore, the current study demonstrates that word-formation units and categories carry out an important text-forming function. Textual unity at the local level can be achieved through the repetition of a formant or a base shared by derivatives in adjacent or distant sentences. The 'source word - derivative' word-formation pair that establishes derivational relations has a great cohesive potential. Syntactic derivation is especially important for the unfolding and communicative progression of text. The components of complex word-formation units - word-formation paradigms, wordformation families - that share the same root morpheme, the bearer of general semantic meaning inherent in all members of a paradigmatic grouping, can be used as a means of textual coherence.

\section{REFERENCES}

[1] Слюсарева Н.А. (Ред.) Аспекты общей и частной лингвистической теории текста. Наука, Москва, 1982.

[Slyusareva N.A. (Ed.) Aspekty obshchey i chastnoy lingvisticheskoy teorii teksta. Nauka, Moskva, 1982.]

[2] Бацевич Ф., Кочан І. Лінгвістика тексту. ЛНУ ім. Івана Франка, Львів, 2016.

[Batsevych F., Kochan I. Linhvistyka tekstu. LNU im. Ivana Franka, Lviv, 2016.]

[3] Грещук В.В. Словотвір і художній текст. В: Грещук В.В., Кононенко В.І., Хороб С.І. Василь Стефаник-художник слова. Пиай, Івано-Франківськ, 1996, 108-114.

[Greshchuk V.V. Slovotvir i khudozhnii tekst. In: Greshchuk V.V., Kononenko V.I., Khorob S.I. Vasyl Stefanyk - khudozhnyk slova. Plai, Ivano-Frankivsk, 1996, 108-114.]

[4] Загнітко А.П. Лінгвістика тексту. Теорія і практикум. ДонНУ, Донецьк, 2006.

[Zahnitko A.P. Linhvistyka tekstu. Teoriia i praktykum. DonNU, Donetsk, 2006.]

[5] Земская Е.А. Словообразование и текст. Вопросы языкознания, 6 (1990), 17-30.

[Zemskaya E.A. Slovoobrazovaniye i tekst. Voprosy yazykoznaniya, 6 (1990), 17-30.]

\footnotetext{
* Plakhta - an outer garment; thick checkered cloth wrapped by Ukrainian girls and younger women around the waist over the shirt (as a kind of skirt) [7, p. 388].
} 
[6] Ковтунова И.И. Вопросы структуры текста в трудах акад. В. В. Виноградова. В: Иванов В.В., Шведова Н.Ю., Аяпон М.В. Русский язык. Текст как иелое и компоненты текста: Виноградовские чтения XI. Наука, Москва, 1982, 3-18.

[Kovtunova I.I. Voprosy struktury teksta $\mathrm{v}$ trudakh akad. V. V. Vinogradova. In: Ivanov V.V., Shvedova N.Yu., Lyapon M.V. Russkiy yazyk. Tekst kak tseloye i komponenty teksta: Vinogradovskiye chteniya XI. Nauka, Moskva, 1982, 3-18.]

[7] Корунець І.В. Теорія і практика перекладу (аспектний переклад). Нова Книга, Вінниця, 2003.

[Korunets I.V. Teoriia i praktyka perekladu (aspektnyi pereklad). Nova Knyha, Vinnytsia, 2003.]

[8] Курилович Е. Деривация лексическая и деривация синтаксическая. В: Курилович Е. Очерки по лингвистике. Изд-во иностранной литературы, Москва, 1962, 57-70.

[Kurilovich E. Derivatsiya leksicheskaya i derivatsiya sintaksicheskaya. In: Kurilovich E. Ocherki po lingvistike. Izd-vo inostrannoy literatury, Moskva, 1962, 57-70.]

[9] Лукин В.А. Художественный текст: Основы хингвистической теории. Аналитический минимум. 2-е изд., перераб. и доп. Ось-89, Москва, 2005.

[Lukin V.A. Khudozhestvennyy tekst: Osnovy lingvisticheskoy teorii. Analiticheskiy minimum. 2-e izd., pererab. i dop. Os-89, Moskva, 2005.]

[10] Мурясов Р.3. Словообразование и теория номинализации. Вопросы языкознания, 6 (1989), 39-53.

[Muryasov R.Z. Slovoobrazovaniye i teoriya nominalizatsii. Voprosy yazykoznaniya, 6 (1989), 39-53.]

[11] Полюжин М. Функціональний і когнітивний аспекти англійського словотворення. "Закарпаття", Ужгород, 1999.

[Poliuzhyn M. Funktsionalnyi i kohnityvnyi aspekty anhliiskoho slovotvorennia. "Zakarpattia", Uzhhorod, 1999.]

[12] Dokulil M. Tvoření slov v češtině. Teorie odvozování slov. Nakladatelství Československé akademie věd, Praha, 1962. (in Czech)

[13] Ukrainka L. Hope. Selected Poetry. Translated into English by Gladys Evans. Dnipro, Kyiv, 1975.

Address: Vasyl Greshchuk, Vasyl Stefanyk Precarpathian National University, 57, Shevchenko Str., IvanoFrankivsk, 76025, Ukraine.

E-mail: ukrinst.pu.if@gmail.com

Received: 17.04.2018; revised: 27.11.2018.

Грещук Василь. Словотвірні засоби когезї та когерентності тексту. Журнал Прикарпатського університету імені Василя Стефаника, 6 (2) (2019), 71-78.

У статті аналізуються словотвірні засоби когезіі та когерентності тексту. Встановлено, що локальну зв'язність тексту може забезпечувати повторення одного суфікса, префікса, конфікса або твірної основи в контактно чи дистантно розміщених реченнях невеликих сегментів тексту. Важливим чинником когезії тексту є словотвірна пара “твірне - похідне”. Особливо це характерно для синтаксичної деривації. Номіналізація дієслова - предиката вихідного речення, в якому воно є комунікативним ядром, та включення його до складу наступного речення, яке може бути розміщено безпосередньо за ним або дистантно як тема забезпечуе комунікативні перспективи висловдювання при розгортанні, прогресії тексту. Словотвірні пари базової та результативної одиниць словотвору поза межами синтаксичної деривації - в мутації та модифікації теж можуть бути засобом реалізації когезії тексту. Як засіб когерентності тексту можуть використовуватися компоненти комплексних словотвірних одиниць - словотвірних парадигм, словотвірних гнізд. Ця їх властивість грунтуеться на спідьності кореневої морфеми - носія загальної семантичної ідеї, притаманної усім членам парадигматичного утворення.

Ключові слова: когезія, когерентність, текст, формант, твірна основа, словотвірна парадигма, словотвірне гніздо. 